\title{
SEA LEVEL RISE INUNDATION RISK ASSESSMENT IN RESIDENTIAL CADASTRAL PARCELS ALONG THE MEDITERRANEAN ANDALUSIAN COAST
}

\author{
JOSÉ OJEDA-ZÚJAR*, PABLO FRAILE-JURADO, \\ JOSÉ ÁLVAREZ-FRANCOSO
}

\begin{abstract}
Departamento de Geografía Física y Análisis Geográfico Regional,
\end{abstract} Universidad de Sevilla, 41004 Sevilla (Spain)

\begin{abstract}
The general objective of this article is to present the methodological approach for the assessment of the inundation risks associated with the rise in the mean sea level for different models and scenarios of climatic change (IPCC, 2013 and Jevrejeva et al., 2012). The approach focuses on the assessment of the hazard, exposure and physical vulnerability of the built areas, especially the residential areas along the Mediterranean coast of Andalusia (Spain). For hazards calculation a set of tide gauges' data and climatic scenarios were analyzed to obtain future sea levels for all the spectrum of probabilities. Further, a method is proposed for mapping the probability associated with each scenario using a $5 \mathrm{~m}$ cell size DTM. For exposure and vulnerability assessment of built up areas, especially for residential ones, the National Cadastre, which is the most detailed set of data, have been used. Modeling the original cadastral data in a spatial database management system and their analysis through SQL sentences have made possible to identify the cadastral parcels with residential use and associated variables (area, number of residential real estate units, constructed area below ground, etc..), being therefore the cadastral parcel the spatial reference unit for mapping. The overlay of cadastral parcels and the inundation hazard maps has allowed identifying the residential cadastral parcels exposed to each climatic scenario. A method is proposed for better identification of the number of real estate units in each cadastral parcel, assuming this number as the base for residential parcel vulnerability. Finally, the risk assessment is calculated as the product of the previous variables. For the dissemination of the inundation risk assessment results, a web application (geoviewer) was developed. Results show that for the more pessimistic scenario more than 24,000 exposed cadastral parcels would be affected. Out of that, 13,000 exposed residential cadastral parcels were identified and their hazards, exposure and vulnerability calculated in order to map the final inundation risk associated with future sea levels.
\end{abstract}

\section{Evaluación del riesgo de inundación por subida del nivel del mar para parcelas residenciales catastrales en la costa Mediterránea andaluza}

RESUMEN. El objetivo general de este artículo es presentar los principales resultados metodológicos de la evaluación de los riesgos de inundación permanente asociados con el aumento del nivel medio del mar según diferentes escenarios y modelos de cambio climático (IPCC, 2013 y Jevrejeva et al., 2012), centrándose en la evaluación de la peligrosidad, la exposición y la vulnerabilidad física de las áreas construidas, especialmente las áreas residenciales en la costa mediterránea de Andalucía (España). Para el cálculo del riesgo se trató un conjunto de datos de mareógrafos y escenarios climáticos para obtener finalmente los niveles futuros para todo el espectro de probabilidades. En este trabajo se propone un método de análisis espacial del riesgo de inundación asociado a cada escenario de subida del nivel del mar mediante el uso de un DTM de $5 \mathrm{~m}$ de resolución espacial. Para la evaluación de la exposición y la vulnerabilidad del área edificada, especialmente para las áreas residenciales, se ha utilizado el conjunto de datos más detallado (Catastro Nacional). El modelado de los datos catastrales originales 
en un sistema de gestión de bases de datos espaciales y su análisis a través de sentencias SQL han permitido identificar las parcelas catastrales con uso residencial y las variables asociadas (área, número de unidades inmobiliarias residenciales, área construida bajo tierra, etc.), constituyendo la parcela catastral la unidad de referencia espacial para el análisis espacial. La superposición del conjunto de parcelas catastrales y los mapas de riesgo de inundación permitieron identificar la exposición de las parcelas catastrales de uso residencial para cada escenario elegido. Se propone un método para una mejor identificación del número de inmuebles residenciales en cada parcela catastral, ya que este número será utilizado como indicador de la vulnerabilidad física de la parcela catastral. La evaluación del riesgo de inundación se calculó como el producto de las variables anteriores. Para la difusión de los resultados de la evaluación del riesgo de inundación, se desarrolló una aplicación web (geovisor). Utilizando el escenario más pesimista, las parcelas expuestas ascienden a más de 24.000 y se identificaron más de 13.000 parcelas catastrales residenciales expuestas para las que se calcularon sus riesgos, exposición y vulnerabilidad para evaluar finalmente el riesgo de inundación asociado a los niveles futuros del mar.

Key words: SLR inundation hazards, physical vulnerability, residential cadastral parcels, web geoviewer, Mediterranean Andalusian coast.

Palabras clave: Inundación por subida del nivel del mar, vulnerabilidad física, parcelas catastrales residenciales, geovisor, costa mediterránea andaluza.

Received: 16 June 2020

Accepted: 18 December 2020

Corresponding author: J. Ojeda Zujar. Departamento de Geografía Física y Análisis Geográfico Regional. Universidad de Sevilla, 41004-Sevilla (Spain). E-mail address: zujar@us.es

\section{Introduction}

Global sea level has risen since the late $19^{\text {th }}$ century around $12-18 \mathrm{~cm}$. An acceleration in its trend has been detected by tide gauges and altimetry satellites during the recent decades. Trends since 1992 have been measured in about $3.4 \mathrm{~mm} /$ year, doubling the maximum threshold of sea level rise (SLR) for the period covering the $20^{\text {th }}$ century. The idea of using SLR as a direct consequence of the climate change has increased scientific consensus in recent years. There is a strong scientific consensus in linking SLR with the climate change caused essentially by anthropogenic emissions of greenhouse gases (Nicholls and Cazenave, 2010; Church et al., 2013).

For the last two decades, several forecast of SLR have been made, showing the upward expectations based on different emission scenarios. Although they involve a wide range of parameters, all of them conclude that SLR shows an inertia that it is very likely that it will continue rising during the $21^{\text {st }}$ and even the $22^{\text {nd }}$ century despite the emission scenario chosen (Titus and Narayanan, 1995; Kopp et al., 2015). Therefore, most of the scientific discussion has been focused on the range of the SLR, which vary not only due to the emission scenarios but also due to the climate change model being used. The most robust models synthetize a vast quantity of data and types of variables, having been led by IPCC models for the last three decades. IPCC's last reports (2019), despite the scenario chosen, often predict rises of 0.4 to $0.9 \mathrm{~m}$ by the year 2100 . On the other hand, the so-called semi-empirical models estimate that SLR might reach up to $2 \mathrm{~m}$ by the year 2100 (Rahmstorf, 2007; Pfeffer et al., 2008; Rahmstorf, 2010). The difference between both types of models lies on the apparently inadequate modeling of the melting process of Greenland (Gardner et al., 2013; Rignot, et al., 2011; Shepherd and Wingham, 2007). 
Nevertheless, any work dealing with the local consequences of a SLR should focus not only in the global processes but also in the importance of the local factors (Zazo Cardeña et al., 2003; Zhang et al., 2011; Sayol and Marcos, 2018), which might amplify the local rise trends (due to local subsidence or due to the compaction of sediments) or decrease them, sometimes even inversing them (Johansson et al., 2014).

Different methods have been developed for assessing vulnerability of different coastal systems to climate change impacts. However, one of the common challenges of measuring vulnerability is that vulnerability is temporally dynamic and context specific, because exposure, sensitivity and adaptive capacity vary by type, by stimulus and are place and system specific (Smith and Wandel, 2006).

At this point, it is important to make the distinction between the concepts of flooding, linked to occasional extreme events related essentially to the state of the atmosphere, and inundation which is the occupation of the emerged surface by high tide waters. This second concept is the one in which this work is focused. There are two main types of approaches for evaluating the possible damage caused by the risk of SLR. The first type lies on the calculation of relative indicators of vulnerability, based on the characterization of coastal sectors by means of different variables that indicate the exposure and the value of each analyzed section. It is a very common approach that allows an easy identification of the most vulnerable places (Ojeda et al., 2009; Fraile-Jurado et al., 2019)

The second approach consists on the application of natural risk analysis, in which risk is understood as the probability that a territory (including the society that inhabits it) is affected by natural episodes of extraordinary range. Therefore, the risk is considered as the result of the product of hazard, exposure and vulnerability. The hazard can be defined as the probability of occurrence of a specific adverse event, and it is often provided in terms of values ranging between 0 and 1 . The exposure is the probability that a surface element is affected by an adverse event and for the purpose of this paper it can be considered as the hazard mapping. The vulnerability comprises the characteristics and circumstances of a community or system that make them susceptible to the damaging effects of a threat, depending both on their value and also on their resilience.

This approach allows the development of very precise spatial analysis using Digital Elevation Models (DEM) as for instance the work of Gesch (2018). However, the definition of this conceptual framework is complex and allows many interpretations for permanent inundation processes. The hazard is usually valued by means of a single value that represents a permanent flood level, which is linked to the mean value of occurrence according to the statistical model by which the inundation level is calculated. The exposure is very commonly represented by means of dichotomous maps that only distinguish between potentially inundable surfaces and non-inundable surfaces. Therefore, often the probability threshold that distinguishes both surfaces is that of $\mathrm{p}>0.5$. However, some authors (Purvis et al., 2008, Fraile-Jurado et al., 2017) have stated that there are much more open approaches that allow the inclusion of a greater spectrum of probabilities, integrating complete statistical models. Finally, the vulnerability presents the greatest conceptual and methodological dispersion of the aforementioned three, since an enormous variety of approaches have been identified, taking into account elements as different as the economy, the population, the value of the exposed elements, and the resilience (TascónGonzález et al., 2020). Here, the residential physical vulnerability of cadastral parcels was used, mainly due to the detailed scale of the National Cadastre, in line with recent works (Jongman et al., 2014; PerezMorales et al., 2016). Thus, it makes more sense to use the risk terminology of an element to sea level rise, that element being the population, housing or infrastructure, since the complete vulnerability of the entire society and environment in a given territory has not been included in any work on floods caused by rising sea levels. 


\section{Study area and objectives}

The general objective of this article is to present the main methodological results of the assessment of the inundation risks associated with the rise in the mean sea level for different scenarios of climatic change (IPCC, 2013; Jevrejeva et al., 2012), focusing on the assessment of the hazard, exposure and vulnerability of the built areas, especially the residential areas along the Mediterranean coast of Andalusia (Spain). This methodology has been developed in the framework of various Research Projects funded by the Andalusian regional government (see "acknowledgements"). Andalusia region has an exposed coastline of $917 \mathrm{~km}$ long, which is divided into two clearly distinct coastal areas (Fig. 1). The Atlantic coast, approximately $300 \mathrm{~km}$ long and the Mediterranean coast (just over $600 \mathrm{~km}$ long) that constitutes the study area for this work. The Mediterranean coast of Andalusia includes the provinces of Málaga, Granada and Almería, as well as part of the coast of Cádiz and it is characterized by a microtidal regime with short-fetch waves. This is a morphostructural coast controlled by Baetic System, with an inland abrupt and steeply sloped relief with a narrow coastal platform. The result is a heterogeneous coastal fringe with cliff headlands and pocket beaches, medium to large beaches associated with riverine sediments and deltas, as well as lagoons associated with former spits and beach barrier sediments. A large number of coastal infrastructures has also played an important role on coastal dynamic processes (Manno, et al., 2016). Intensive agriculture and tourism are ones of the main economic activities. The tourism accounts for 13,1\% of the regional GDP (Junta de Andalucía, 2016) on the regional economy, being an important driver in the Mediterranean coast (Costa del Sol).

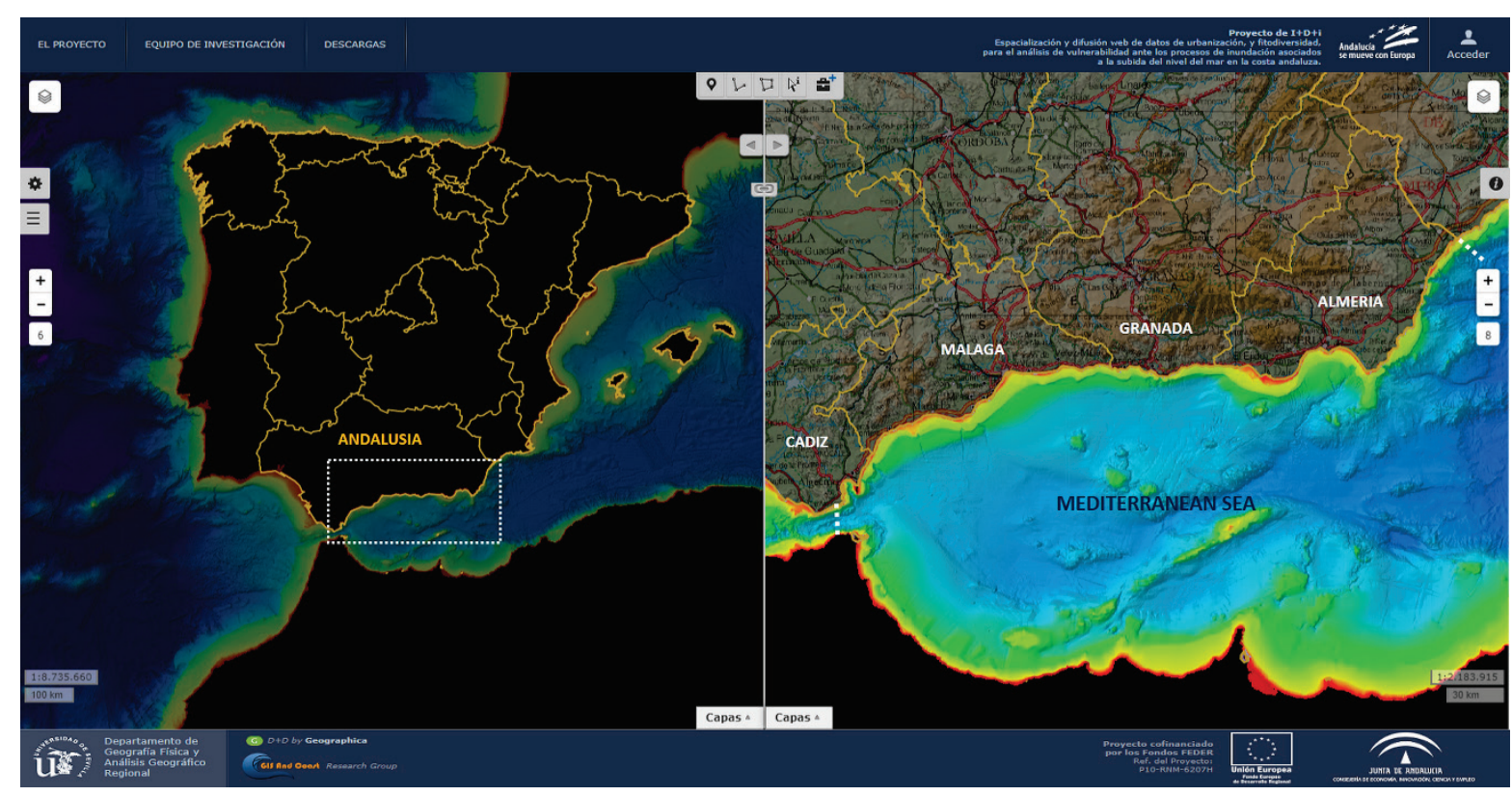

Figure 1. Study area. The Mediterranean coast of Andalusia (600 km long) includes all the coastline of the provinces of Málaga, Granada and Almería, as well as part of the one of Cádiz. Image extracted from the web client (geo-viewer) developed in the project.

For the correct interpretation of this article, it is necessary to emphasize that it focuses exclusively on the risks of permanent flooding (inundation), not including extreme events (flooding) that add to the previous ones those related to storms, waves extremes, surges, or tsunamis. In this sense, the following specific objectives are identified:

1. Sea level rise inundation hazard assessment. Calculating the probability that an inundation event of a particular intensity will occur over an extended period of time. Data from tide gauges and from 4 climatic change scenarios will be used. Unlike many publications that select a probability threshold to identify the exposed lands (generally $>50 \%$ ), in this case the entire range of 
probabilities will be calculated, in order to evaluate the differences between both methodological approaches.

2. Inundation hazards mapping. To spatialize the calculated hazard sea levels on the tide gauges and scenarios, a DTM of 5 meters spatial resolution was used (National Geographic Institute). We are aware of the low precision and accuracy of this DTM, so the results should be interpreted with caution and more as an "indicator" of potential areas where priority should be given and detailed studies with more accurate altimetry data (LIDAR) will be required.

3. Exposure and Physical Vulnerability assessment of residential areas. The calculation is made by the combination of inundation hazard maps with the most detailed information published periodically in the Spanish state (National Cadastre) for constructed areas. National Cadastre uses 1: 500 or 1: 1000 scales for urban areas (cadastral parcel files -CAT format). The methodological proposal is based on modeling of the original information in a spatial database. Therefore, and given the guarantee of periodic publication, the use of defined SQL statements would allow an almost automatic update of future data.

4. Risk assessment for residential areas. Once the hazard, exposure and vulnerability have been calculated and mapped, the risk calculation is methodologically simple, since it is simply a matter of obtaining the product of the three variables.

5. The development of a Web application (geoviewer), which makes use of interoperable OGC web services, in order to provide scientists and stakeholders with a web tool to access and visualize the project results.

\section{Data and methods}

\subsection{Inundation hazards assessment and mapping}

\subsubsection{Mean sea level inundation hazard assessment}

The goal of inundation hazard assessment is to understand the probability that an inundation event of a particular intensity will occur over an extended period of time. Data from tide gauges and from 4 climatic change models/scenarios will be used. Particularly, data from SLR expectations in the Andalusian tide gauges by the end of the $21^{\text {st }}$ century (Fraile-Jurado and Fernández Díaz, 2016) were used for this part of the study. They were calculated by means of the integration of registered SLR trends and four different climatic model/scenarios. Three of them were made by the IPCC (Gregory, 2013) and another one can be considered as a semi-empirical model (Jevrejeva et al., 2012) ("model of Jevrejeva" hereafter) (Table 1), all of them widely discussed (Meyssignac and Cazenave, 2012; Williams, 2013).

Table 1. Mean and standard deviation parameters of the SLR scenarios and models.

\begin{tabular}{|l|c|c|c|}
\hline Model & Scenario & Mean SLR & Standard Deviation \\
\hline IPCC (2013) & RCP2.6 & $0.40 \mathrm{~m}$ & $0.091 \mathrm{~m}$ \\
\hline IPCC (2013) & RCP6.0 & $0.47 \mathrm{~m}$ & $0.097 \mathrm{~m}$ \\
\hline IPCC (2013) & RCP8.5 & $0.63 \mathrm{~m}$ & $0.115 \mathrm{~m}$ \\
\hline Jevrejeva et al. (2012) & - & $0.84 \mathrm{~m}$ & $0.12 \mathrm{~m}$ \\
\hline
\end{tabular}


As stated by Fraile-Jurado et al. (2019), the first step in this phase consists of calculating the maximum possible inundation levels considering three variables:

- SLR expected locally in each tide gauge (Fraile-Jurado and Fernández Díaz, 2016).

- The vertical difference between the topographic zero and the local mean sea level.

- The local height of the high tide for a tide coefficient of 0.7. The last term was included because it allows to add an extra height to the inundation level. This allows to avoid possible errors of the DTM, which often seem to lose accuracy in altitudes near mean sea level. Moreover, the high tide level is a common indicator to estimate flooding and inundation exposure.

The first variable was calculated with data from the tides gauges located in the Andalusian coast, integrating this information into the global models of SLR. This step allows to make subsequent estimations of the SLR for any given probability value (Table 2). The second variable consists of the observed differences between the local mean sea level and the national vertical reference (topographic zero) of topographic maps. Although in the study area it is not very relevant, ranging between $0.12 \mathrm{~m}$ in the Strait of Gibraltar and close to 0 values in the eastern coast, in other areas it has proved to be a variable which might be even larger than the future SLR (Fraile-Jurado et al., 2014). There is a similar situation for the third variable, since the tidal range shows small values (ranging from 0.5 in the Strait of Gibraltar to $0.3 \mathrm{~m}$ in Almería) and small spatial variability.

Table 2. Expected SLR $(m)$ in the tide gauge of Malaga (first variable) for different probability thresholds, models and scenarios.

\begin{tabular}{|l|c|c|c|c|c|c|c|c|c|}
\hline Model & Scenario & $99 \%$ & $95 \%$ & $75 \%$ & $50 \%$ & $25 \%$ & $10 \%$ & $5 \%$ & $1 \%$ \\
\hline IPCC (2013) & RCP2.6 & 0.23 & 0.29 & 0.38 & 0.44 & 0.50 & 0.56 & 0.59 & 0.65 \\
\hline IPCC (2013) & RCP6.0 & 0.28 & 0.35 & 0.45 & 0.51 & 0.57 & 0.63 & 0.67 & 0.74 \\
\hline IPCC (2013) & RCP8.5 & 0.40 & 0.48 & 0.59 & 0.67 & 0.75 & 0.82 & 0.86 & 0.94 \\
\hline Jevrejeva et al. $(2012)$ & - & 0.60 & 0.68 & 0.80 & 0.88 & 0.96 & 1.03 & 1.08 & 1.16 \\
\hline
\end{tabular}

\subsubsection{Inundation Hazards Mapping}

The results obtained in the previous step would allow to estimate the value of the local inundation level by the end of the $21^{\text {st }}$ century in a single tide gauge considering the aforementioned three variables, with a SLR probability value of $\mathrm{P}>0.5$ for each of the four selected scenarios of change in sea level. However, this method is based on calculating the full spectrum of probabilities, so the next step in the process described by Fraile-Jurado et al. (2019) consists of the mapping and estimation of the full probability values of permanent inundation for each of the DTM cells of the study area, according to the four considered models/scenarios.

The baseline data used was a Digital Terrain Model (DTM) which covers the totality of the Spanish surface (Instituto Geográfico Nacional, 2013). It was made as part of the first coverage of the National Plan of Aerial Orthophotography (PNOA), and it was downloaded from the CNIG download Center in 2014. The precision and accuracy of the original LIDAR flight used for its elaboration was of $0.5 \mathrm{~m}$ for LIDAR points density and a vertical accuracy (RMSz) of 0.2-0.4 m. However, the final estimated vertical accuracy for the MDT downloaded file, at 5 meters spatial resolution (MDT05), was $\geq 0.5 \mathrm{~m}$. Currently there are new versions of this LIDAR MDT with improved precision and accuracy. In this sense, the proposed methodology could be directly used with the original LIDAR cloud or new versions of higher quality MDT, but the extension of the study area and the treatments required prior to its use, made this option unfeasible in the context of the project, carried out with the technology and data available in the period 2011-2016. 
Previous treatment was carried out on downloaded DTM to eliminate the presence of holes and other types of endorheic areas by filling the surface using the ArcGIS 10 "fill" command. This type of analysis allows better operation of the bathtub-type models and guarantees the hydrologic connectivity to sea water level. A second modification consisted in subtracting from the DTM the interpolated surface integrated by the tree variables (average local SRL level + differences to topographic zero level +0.7 coefficient high tide level) obtained in the previous step (Fraile Jurado and Ojeda Zújar 2012).

The second stage therefore consisted on inundation hazard mapping. To do so, the calculation of the probability of permanent inundation from an accumulated normal statistical model was performed, based on the parameters of normality and standard deviation obtained for each of the four selected models/scenarios (Table 1). Therefore, the value of each cell of the DTM was transformed by means of the following equation (Piña-Monarrez, 2015) which describes an accumulated normal curve (Fig. 2):

$$
p(x)=\frac{1}{2}\left[1+\operatorname{erf}\left(\frac{x-\mu}{\sigma \sqrt{2}}\right)\right]
$$

where $p(x)$ is the probability of inundation for a given height above mean sea level; $x$ is the height of a cell above mean sea level; $\mu$ is the future mean inundation height under the defined inundation conditions; $\sigma$ is the standard deviation in IPCC scenarios (2013) and Jevrejeva (2012).

As a result, an inundation probability was obtained for each cell and for each of the four models/scenarios analyzed analyzed (Fig. 3). Given that the model is an asymptotic statistical model, it was necessary to limit the value of the upper limit of the results to the average plus three standard deviations. However, this calculation was not necessary for the lower limit since the current inundated area by the high tide was also calculated by means of a bathtub model.

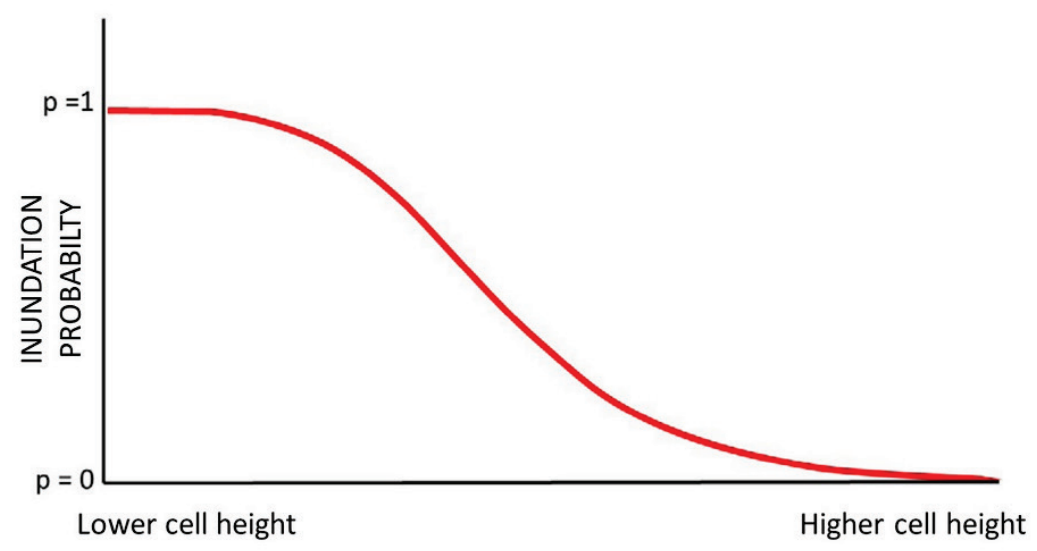

Figure 2. Applied accumulative statistical model of the normal distribution, in which the highest cells get lower probability of inundation and the lower cells get higher probability of inundation. 


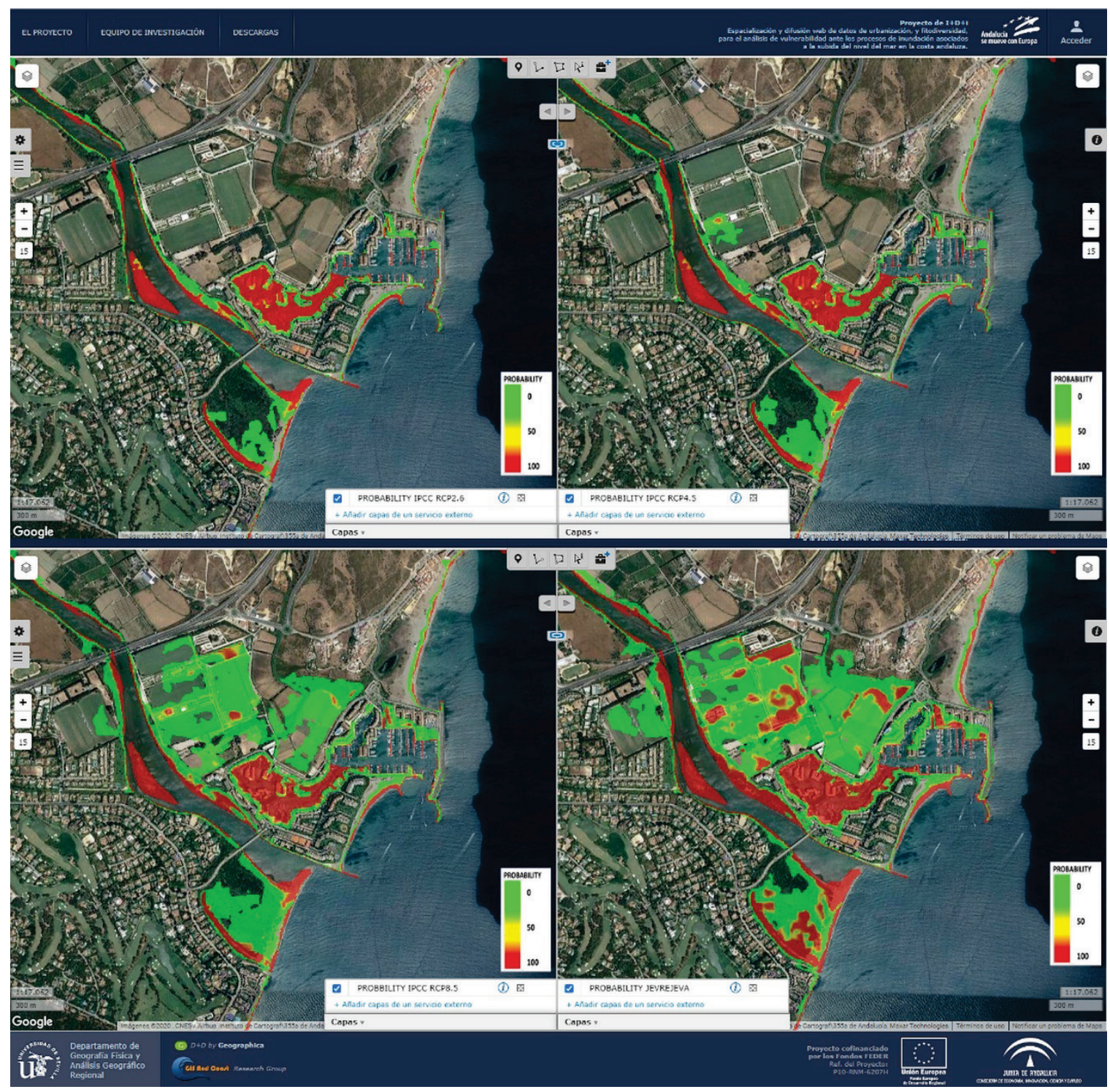

Figure 3. Four geographically synchronized views in the web client (geo-viewer) developed in the Project (Guadiaro river mouth-Cádiz-): examples of hazards mapping for the scenarios and models selected (RCP 2.6, RCP 4.5 y RCP 8.5 from IPCC 2013 and Jevrejeva 2012).

\subsection{Exposure and physical vulnerability assessment of residential cadastral parcels}

As stated before, the goal of vulnerability assessment is to understand how a system will be affected by an inundation event. Examples of possible systems could include physical structures such as houses or bridges that could be damaged or destroyed, a business or service whose supply chain could face interruption, or a community that could suffer fatalities, property losses, and negative health impacts in the aftermath of a flood. Therefore, there are different types of vulnerability, but this paper focuses mainly on physical vulnerability -meaning the vulnerability of the built environment to suffer inundation due to mean sea level rise-, and especially along residential cadastral parcels.

\subsubsection{Data source: The Spanish National Cadastre}

The Spanish Cadastre is an administrative record of properties with a fiscal origin, created as a data bank to be accessed both by Public Administrations (national, regional, local) and citizens. As an inventory of real estate, it contains physical information (surfaces, location, use, shape, boundaries, cartographic representation, crops and forest use, type and quality of constructions, etc.), legal 
information (identification of holders or owners: name, national identification number, address, etc.) and economic information (cadastral values of land and buildings, valuation criteria).

The download of public data could be done using a digital certificate through the Electronic Office of the Cadastre, on the website of the General Directorate of Cadastre. (http://www.catastro.meh.es/). On the website the information is available for each municipality individually, and both the alphanumeric data (CAT format) and the geometric data (shape format) are linked to the rustic and urban areas.

The alphanumeric data is provided in a flat text file with alphanumeric content of 1,000 characters per line, delimited by a fixed width (CAT format). These data contain, for each real estate, information related to each farm, constructive unit, construction, real estate, distribution of common elements and cultivation register, as the case may be, in addition to the head and tail registers of the file. For the transfer of flat text data to PostreSQL/PostGIS Database Management System, a Python application has been built that allows the selection, structuring and modeling of data in tables automatically. The result of the process of modeling is reflected in the Figure 4 that contains the tables and their cardinal relationships.

\subsubsection{Exposure calculation of cadastral parcels for different scenarios}

As shown in the Figure 4, the geometric data was provided in shape format (parcels, subparcels, administrative limits, etc.) and among the 3 alphanumeric tables used in this work (cadastral parcels table 11-, constructions -table 14- and real state units -table 15) it is only possible to establish a spatial relationship with the shape parcels. Therefore, the cadastral parcels will be the reference spatial unit (geo-referenced and scaled to 1:500 or 1:1000 in urban areas and 1:5000 or 1:2000 in rural areas) for the analysis of exposure and vulnerability assessment.

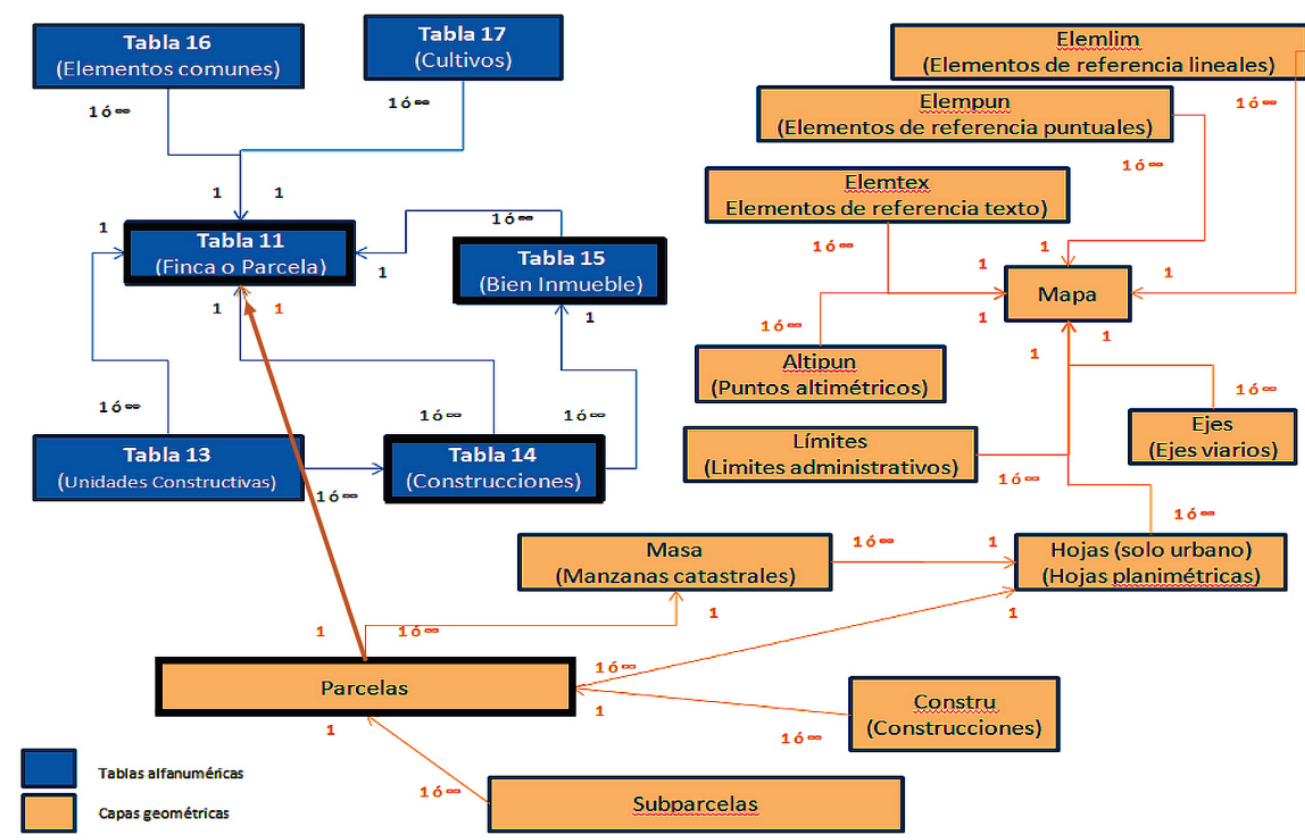

Figure 4. Database model for the Spanish National Cadastre. The only 3 tables used in this work are: table 11: cadastral parcel (finca o parcela); table 14 constructions (construcciones) which records the construction units associated with different possible uses; table 15: real estate units (inmuebles). Only the table 11 has an

alphanumeric relation (parcel register identifier) with the attribute table of geometric layer parcelascadastral parcels-(shapefile). In blue the alphanumeric tables are represented whereas yellow represent the geometric shapefiles. 
Methodologically, the calculation of the exposure for each of the cadastral parcels has been carried out with the software ArcGis 10.3 software, using a set of tools available in Spatial Analyst toolbox. The use of raster analysis tools allows to extract for each of the parcels (polygons) the number of pixels present in each of the raster layers (hazard maps) associated with the probability of inundation hazards for each of the models/scenarios selected in this work, as well as to calculate various statistics (average, variety, STD, etc.) that were incorporated into the attribute table of the shape (see Fig. 5).

On the other hand, from the alphanumeric data in table 11 two relevant variables for the final calculation of risk were extracted:

- Dominant use of the cadastral parcels, which is the majority use of all its components (real estate units).

- Total constructed area in $\mathrm{m}^{2}$, making the sum of all the space built on all the floors (above and below ground) of the buildings or facilities within each cadastral parcel. In turn, two more variables are also provided:

o the constructed area above ground in $\mathrm{m}^{2}$.

o the constructed area below ground in $\mathrm{m}^{2}$.

Finally, all the variables (probability statistics hazards, dominant use, and constructed areas total, above and below ground-) were incorporated to the attribute table of the shape parcels.

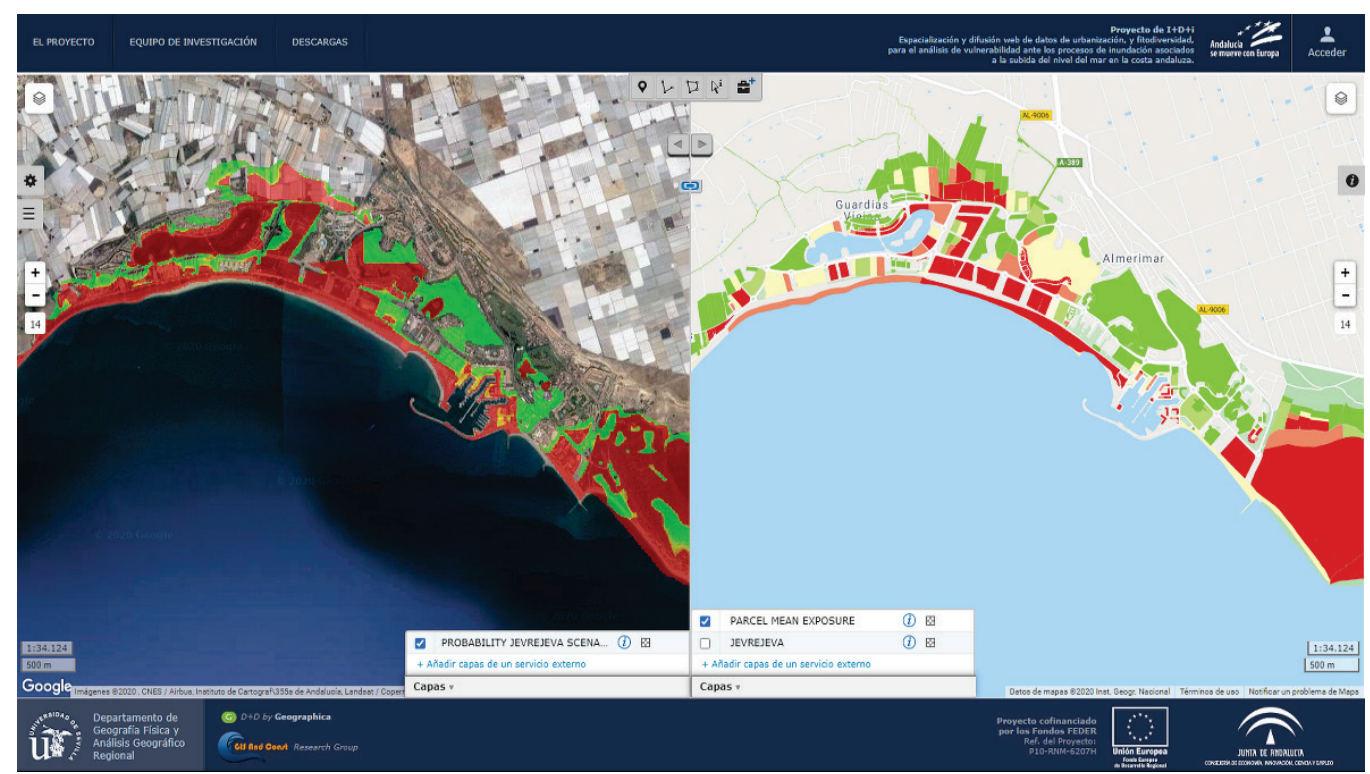

Figure 5. Two geographically synchronized views in the web client (geo-viewer) developed in the Project (western sector of the Almería coast): the entire range of inundation probabilities associated with the Jevrejeva model/scenario (left view) and the average probability associated with the cadastral parcels (right view).

\subsubsection{Calculation of physical vulnerability of cadastral residential parcels}

For residential physical vulnerability calculation of the cadastral parcels, different SQL statements have been used to extract from table 15 (real state units-inmuebles) and table 14 (construcciones -constructions units) the number of real state units -inmuebles - that they have a residential use (tables were shown on Figure 4). Given the impossibility of extracting their economic 
value (a variable not accessible in the Cadastre -CAT format- for the general public), the number of residential real estate units have been used as an "indicator" of physical vulnerability for residential cadastral parcels. Thus, two variables have been used for its calculation:

- Number of real estate units -inmuebles- (table 15). Each entity in this table has a "main use", among which we have selected those that have a residential use

- Number of residential constructions units (table 14). Each entity in this table has a "destination", among which we have selected those that are of residential use. Since the cardinality relationships between table 14 and table 15 are many to one, with this variable we were finally able of calculating the number of the real estate units (inmuebles) where at least one construction unit is intended for residential use.

This second variable increases the number of real state units of residential use (see results) and using the cardinality relationships shown in Figure 4, it is possible to associate its value to the cadastral parcels (table 11). To this regard, the variable chosen to assess the residential physical vulnerability was the "number of real estate units (inmuebles) per cadastral parcel that includes at least one construction unit with a residential destination".

Finally, these variables were incorporated to the attribute table of the cadastral parcels shape, along with the rest of the variables previously calculated for the probability of inundation hazards and exposure (Fig. 6).

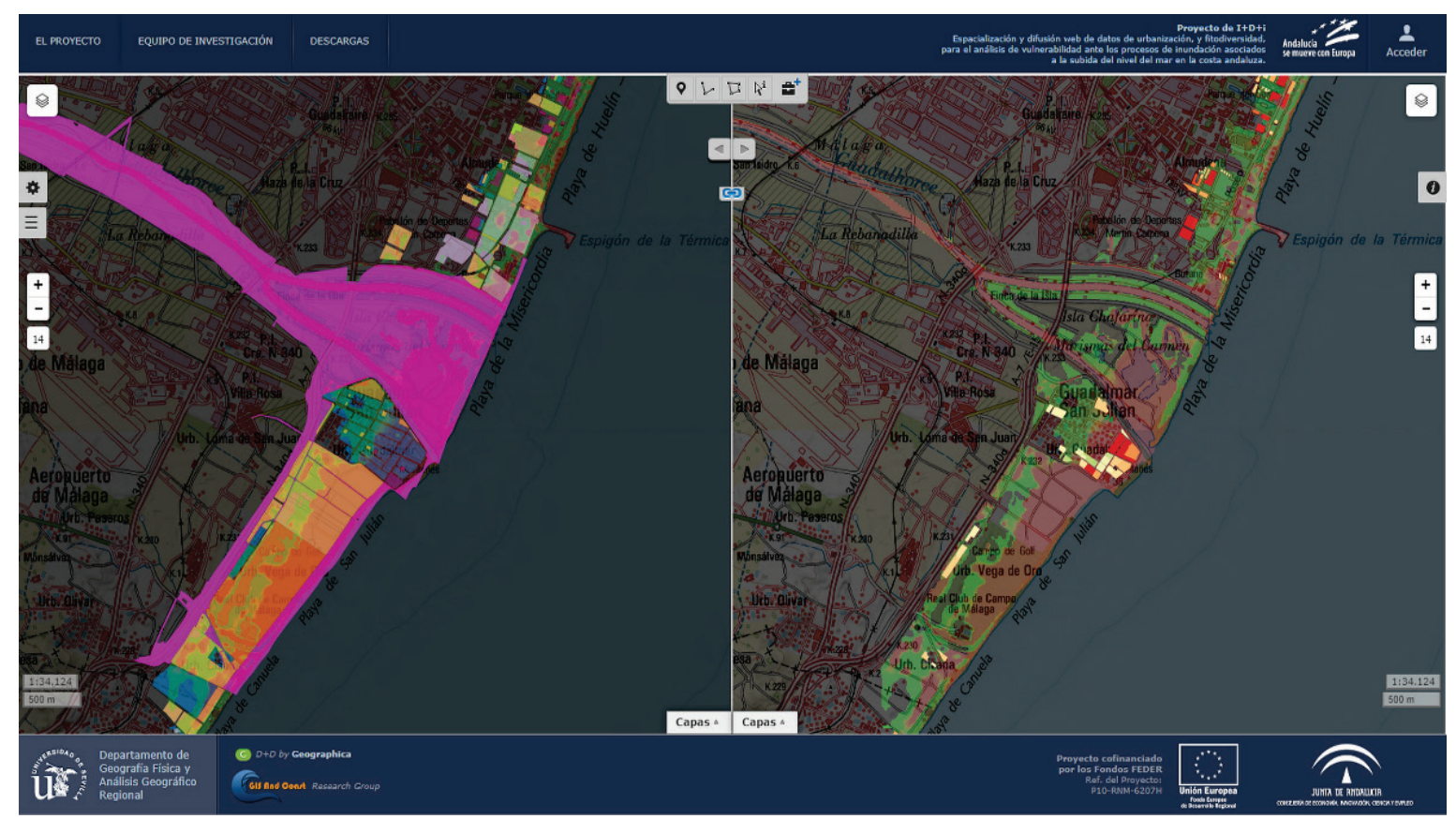

Figure 6. Two geographically synchronized views in the web client (geo-viewer) developed in the Project (Guadalfeo delta river-Málaga coast-): Cadastral parcels according to their dominant use exposed to Jevrejeva model/scenario (left view) and residential cadastral parcels classified according to the number of real estate units (inmuebles) per cadastral parcel that includes at least one construction unit with residential destination, variable finally used for the residential physical vulnerability assessment (right view).

\subsection{Risk assessment for residential cadastral parcels}

Once the inundation hazard, exposure and physical vulnerability assessment have been completed, it is relatively simple to arrive at an estimate of inundation risk, since it is simply a matter of obtaining the product of the three variables. Methodologically it is as easy as working with the 
different variables already included within the attribute table of the cadastral parcel shape: the average probability of the pixels included in each exposed parcels to each of the selected models/scenarios "multiplies by" the number of real estate units (inmuebles) that include at least one construction unit with a residential destination, used as a "dimensionless indicator" for the residential risk assessment (Fig. 7).

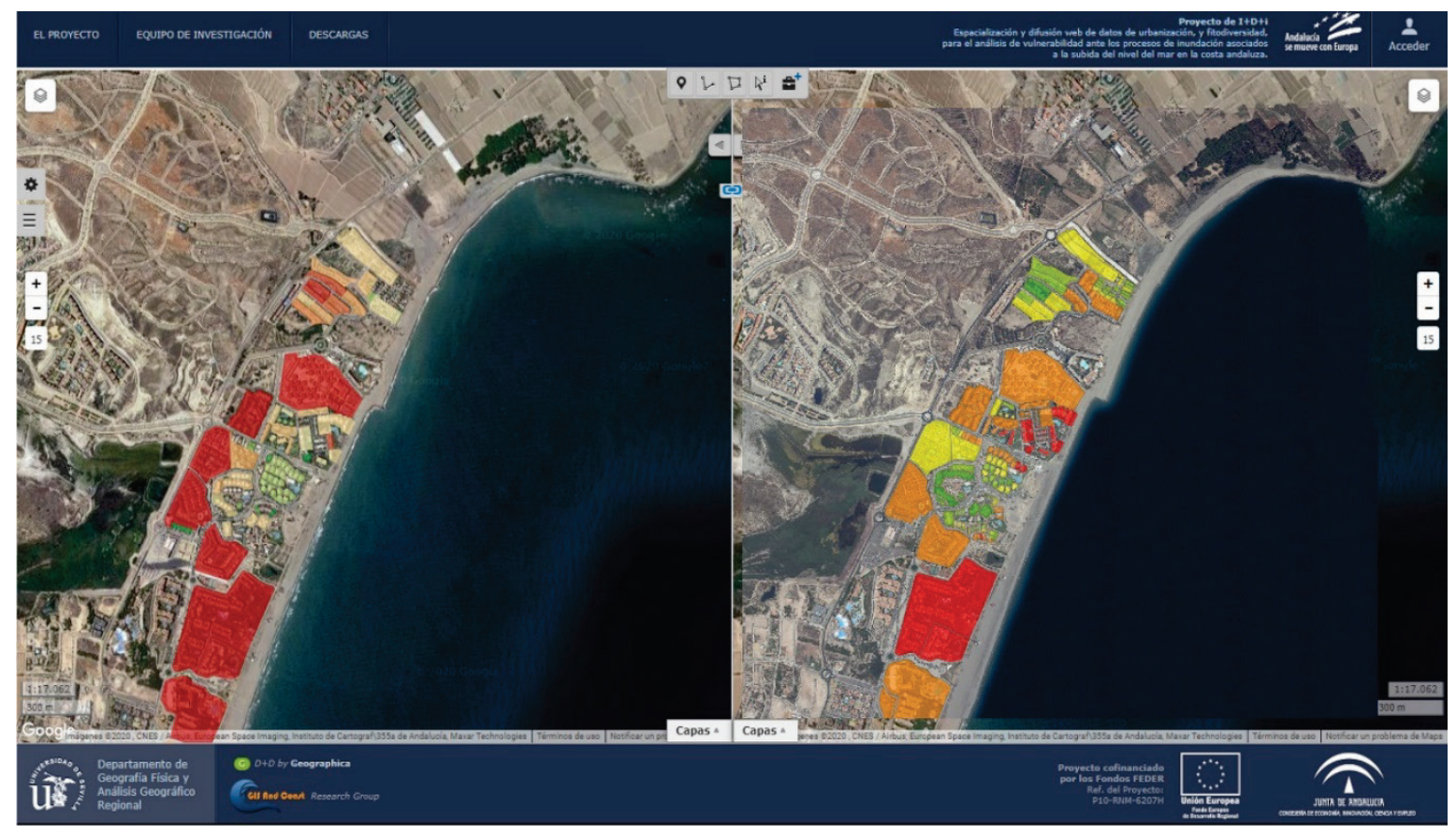

Figure 7. Two geographically synchronized views in the web client (geoviewer) developed in the Project (Almanzora delta river-Almería coast-): Cadastral parcels according to their residential physical vulnerability -number of residential real estate units per parcels-exposed to Jevrejeva model/scenario (left view) and residential cadastral parcels according to their risk, once physical vulnerability is multiplied by the average probability of inundation hazard (right view).

\subsection{Web application (Geoviewer)}

Finally, a geoviewer, a web application, which makes use of interoperable OGC web services, was the option selected for accessing and visualizing the huge amount of spatial data produced in this work. The development of this tools aims to provide scientist and stakeholders a web tool to understand, interpret and respond to mean sea level inundation risk that would threaten coastal regions in order to prevent or mitigate the possible environmental, social or economic loss. Geoviewer's functionalities (variety of cartographic representations, multiple scale visualization, access to thematic information related to coastal hazards and vulnerability assessment, etc.) are being boosted by the new potential of the spatial databases and web mapping services and moreover, by the new possibilities on client side (HTML5, Javascript libraries, WebGL, etc.).

The developed visualization system (web application) makes use, on the server side, of PostgreSQL v. 9.6.0 and its spatial extension PostGIS v. 2.3 for data warehouse. The map server software used to create the OGC interoperable services (WMS, WMTS and WFS) which feed the geoviewer was Geoserver v. 2.8.1. The geoviewer (client side) has been developed over Leaflet, an open source Javascript library for displaying geographic data in browsers. Besides Leaflet, a set of Javascript open libraries were used to add new functionalities to the geoviewer, allowing users the access to external data. 
The visualization system covers the whole coast of Andalusia (Álvarez-Francoso et al. 2020) and the deployment in the back-end has been made very flexible by the use of an Operating-systemlevel virtualization software (Docker). Thus, it could be easily reproduced in any other coastal region due its high flexibility, which has been made possible by the use of virtualization, open source software and standard interoperable services.

\section{Results}

The scale of detail used for the calculations and assessment of all the components of the risk of mean sea level rise inundation over the built up areas, as well as the extension of the study area $(600 \mathrm{~km}$ long), made the use of synthetic cartography complex and many times unfeasible. These were the main reasons that justify the development of a web application for results dissemination, constituting in itself one of the main results of this work. Although there is a vast amount of results accessible through the web application (geoviewer) tool (see most of the figures presented here), only the most relevant results resulting from the calculation of the most pessimistic model/scenario (Jevrejeva, 2012) are presented here.

\subsection{Cadastral parcels exposure according to the type of land use}

Table 3 shows the results related to the exposure of all cadastral parcels in the study area to future sea levels for Jevrejeva scenario, taking into account the type of land use that is dominant among all those present in the cadastral parcel (extracted from table 11 -parcels- shown in Fig. 4).

Table 3. Main figures derived from the cadastral parcels exposed to all the spectrum of probabilities from Jerjereva model/scenario, according their dominant use.

\begin{tabular}{|c|c|c|c|c|c|c|}
\hline $\begin{array}{l}\text { Code } \\
\text { use }\end{array}$ & Parcels dominant use & $\begin{array}{r}\mathrm{N}^{\mathrm{o}} \\
\text { cadastral } \\
\text { parcels }\end{array}$ & $\begin{array}{r}\text { Area of } \\
\text { parcels }\left(\mathrm{m}^{2}\right)\end{array}$ & $\begin{array}{r}\text { Total } \\
\text { constructed } \\
\text { area }\left(\mathrm{m}^{2}\right)\end{array}$ & $\begin{array}{r}\text { Total } \\
\text { constructed } \\
\text { area below } \\
\text { ground }\left(\mathrm{m}^{2}\right)\end{array}$ & $\begin{array}{r}\text { Average } \\
\text { probability } \\
\text { (Jevjereva) }\end{array}$ \\
\hline A & Warehouse-parking & 710 & $1,532,377$ & $2,972,527$ & 744,501 & 24.79 \\
\hline $\mathrm{B}$ & Agrarian warehouse & 4 & 181 & 183 & 0 & 25.39 \\
\hline $\mathrm{C}$ & Commercial & 403 & 664,499 & 757,668 & 25,581 & 23.08 \\
\hline $\mathrm{E}$ & Cultural & 77 & 366,679 & 189,148 & 1,423 & 18.63 \\
\hline $\mathrm{G}$ & Leisure and hostelries & 412 & $1,844,548$ & $1,759,519$ & 156,956 & 22.91 \\
\hline I & Industrial & 806 & $5,366,519$ & $2,326,962$ & 55,259 & 20.76 \\
\hline $\mathrm{J}$ & Industrial agrarian & 21 & 11,971 & 4,989 & 78 & 26.34 \\
\hline $\mathrm{K}$ & Sports & 282 & $17,267,104$ & $14,120,788$ & 21,515 & 23.78 \\
\hline $\mathrm{M}$ & Urbanization and gardening & 2,917 & $43,015,500$ & 251,806 & 3,268 & 27.48 \\
\hline $\mathrm{O}$ & Offices & 79 & 325,268 & 115,050 & 3,051 & 27.98 \\
\hline $\mathrm{P}$ & Singular building & 25 & 202,263 & 187,378 & 13,824 & 24.31 \\
\hline $\mathrm{R}$ & Religious & 21 & 20,755 & 11,629 & 483 & 26.66 \\
\hline $\mathrm{T}$ & Shows & 8 & 8,897 & 4,748 & 380 & 24.10 \\
\hline $\mathrm{V}$ & Residential & 12,761 & $12,671,728$ & $9,364,238$ & $1,478,130$ & 21.12 \\
\hline $\mathrm{Y}$ & Health and charities & 33 & 188,700 & 88,283 & 7,287 & 15.88 \\
\hline \multirow[t]{2}{*}{ Z } & Agrarian & 5,524 & $2,016,365,573$ & 90,541 & 127 & 25.82 \\
\hline & TOTAL OR AVERAGE & 24,083 & $2,099,852,562$ & $32,245,457$ & $2,511,863$ & 22.06 \\
\hline
\end{tabular}

Results show that in this model/scenario (the most pessimistic one) the total number of exposed cadastral parcels amounts to 24,083 and they occupy a total area of more than 209,985 ha. The land uses with the greatest number of exposed parcels are residential, agrarian and those classified as undergoing urbanization. However, if we look at the exposed area of the cadastral parcels, agrarian use stands out, followed by those undergoing urbanization, sports and residential use. Attending to the total constructed 
area (both in total and below ground) the order is first for sports use, followed by residential, the latter being the dominant one if we only attend to the area constructed below ground.

However, when using the $50 \%$ probability threshold, a criterion that is used in many works and publications (Titus and Narayanan, 1995; Purvis et al., 2008) and assuming a dichotomous classification (inundated-not inundated), the results as shown in Table 4 are somehow different. A decrease can be found in all the variables analyzed (as stated in the methodology), reaching $78 \%$ in the number of exposed parcels, $97 \%$ in the total area of the exposed parcels, $85 \%$ in the total constructed area and $63 \%$ in the constructed area below ground.

Table 4. Main figures derived from the cadastral parcels exposed to Jerjereva model/scenario using a threshold in probability (> 50\%), according the dominant use.

\begin{tabular}{|l|l|r|r|r|r|r|}
\hline $\begin{array}{l}\text { Code } \\
\text { use }\end{array}$ & Parcels dominant use & $\begin{array}{r}\text { radastral } \\
\text { parcels }\end{array}$ & $\begin{array}{r}\text { Area of } \\
\text { parcels }\left(\mathrm{m}^{2}\right)\end{array}$ & $\begin{array}{r}\text { Total } \\
\text { constructed } \\
\text { area }\left(\mathrm{m}^{2}\right)\end{array}$ & $\begin{array}{r}\text { Total constructed } \\
\text { area below } \\
\text { ground }\left(\mathrm{m}^{2}\right)\end{array}$ & $\begin{array}{r}\text { Average } \\
\text { probability } \\
\text { (Jevjereva) }\end{array}$ \\
\hline A & Warehouse-parking & 176 & 459,366 & 766,209 & 192,024 & 89.15 \\
\hline $\mathrm{B}$ & Agrarian warehouse & 1 & 51 & 51 & 0 & 98.57 \\
\hline $\mathrm{C}$ & Commercial & 12 & 37,003 & 17,045 & 11,120 & 87.24 \\
\hline $\mathrm{E}$ & Cultural & 89 & 452,142 & 293,275 & 77 & 96.52 \\
\hline $\mathrm{G}$ & Leisure and hostelries & 155 & 605,085 & 355,729 & 9,240 & 88.42 \\
\hline $\mathrm{I}$ & Industrial & 6 & 7,943 & 2,949 & 20,294 & 91.39 \\
\hline $\mathrm{J}$ & Industrial agrario & 35 & 790,472 & 764,635 & 78 & 78.16 \\
\hline $\mathrm{K}$ & Sports & 782 & $9,632,112$ & 41,242 & 187 & 79.48 \\
\hline $\mathrm{M}$ & Urbanization and gardening & 25 & 192,643 & 12,476 & 0 & 84.19 \\
\hline $\mathrm{O}$ & Oorks, unoccupied land & 7 & 118,277 & 116,143 & 0 & 79.24 \\
\hline $\mathrm{P}$ & Singular building & 7 & 4,430 & 3,547 & 179 & 77.71 \\
\hline $\mathrm{R}$ & Religious & 2 & 1,304 & 1,550 & 0 & 79.36 \\
\hline $\mathrm{T}$ & Shows & 2,689 & $3,938,489$ & $2,169,639$ & 0 & 93.07 \\
\hline $\mathrm{V}$ & Residential & 4 & 7,346 & 4,471 & 687,117 & 88.01 \\
\hline $\mathrm{Y}$ & Health and charities & 1,194 & $50,738,591$ & 10,953 & 146 & 85.02 \\
\hline $\mathrm{Z}$ & Agrarian & 5,277 & $67,290,274$ & $4,943,740$ & 31 & 85.08 \\
\hline & TOTAL OR AVERAGE & & & & 920,493 & 86.29 \\
\hline
\end{tabular}

\subsection{Exposure and physical vulnerability of residential parcels (synthesis at provincial level)}

When focusing exclusively on the cadastral parcels that contain some real estate or construction units for residential use, the results are shown in Table 5, also using the exposure derived from the Jevrejeva model/scenario and synthesized at the provincial level.

The first relevant finding is the total number of cadastral parcels for residential use that rises to 13,656 for the study area. This number represents $57 \%$ of the total of exposed cadastral parcels (including all uses), but scarcely represents $1.5 \%$ of the total surface -area of exposed parcels- they occupy (explainable by the wide extension of parcels for agricultural, sports or urbanization use). However, they represent $48 \%$ of the total constructed area (counting any floor, above or below ground), increasing to $87 \%$ if only the below ground constructed area is considered. 
Table 5. Main figures derived exclusively from cadastral parcels exposed to Jerjereva model/scenario containing some real estate or construction units for residential use, synthesized at the provincial level.

\begin{tabular}{|l|r|r|r|r|r|r|r|}
\hline Provinces & $\begin{array}{r}\mathrm{N}^{\mathrm{o}} \\
\text { cadastral } \\
\text { parcels }\end{array}$ & $\begin{array}{r}\text { Area of } \\
\text { exposed } \\
\text { parcels }\left(\mathrm{m}^{2}\right)\end{array}$ & $\begin{array}{r}\text { Total } \\
\text { constructed } \\
\text { area }\left(\mathrm{m}^{2}\right)\end{array}$ & $\begin{array}{r}\text { Total } \\
\text { constructed } \\
\text { area below } \\
\text { ground }\left(\mathrm{m}^{2}\right)\end{array}$ & $\begin{array}{r}\mathrm{N}^{\circ} \text { of real } \\
\text { estate } \\
\text { units }(*)\end{array}$ & $\begin{array}{r}\mathrm{N}^{\circ} \text { of real } \\
\text { estate } \\
\text { units }(* *)\end{array}$ \\
$\begin{array}{r}\text { Average } \\
\text { probability } \\
(\mathrm{Jevjereva})\end{array}$ \\
\hline CÁDIZ (partially) & 4,186 & $9,243,711$ & $2,987,858$ & 240,370 & 19,379 & 19,480 & 16.78 \\
\hline MÁLAGA & 3,403 & $10,011,406$ & $7,478,903$ & $1,041,976$ & 27,198 & 27,416 & 8.75 \\
\hline GRANADA & 2,929 & $1,628,659$ & $2,287,094$ & 367,669 & 20,330 & 20,356 & 48.16 \\
\hline ALMERÍA & 3,138 & $8,754,772$ & $2,839,035$ & 536,138 & 22,397 & 22,568 & 15.76 \\
\hline TOTAL OR AVERAGE & 13,656 & $29,638,548$ & $15,592,890$ & $2,186,153$ & 89,304 & 89,820 & 22.36 \\
\hline
\end{tabular}

* "inmuebles" with main use residential -table 15-

**at least one construction unit -table 14- with residential use

Focusing on the values at provincial level, the number of cadastral parcels for residential use presents similar values, highlighting Cádiz with 4186 (despite only part of the province is included in the study area), followed by Málaga, Almeria and Granada. However, in relation to the area occupied by the cadastral parcels, Málaga (1001 ha) occupies the first place, followed by Cádiz and Almería and, at a great distance, Granada (162 ha). In relation to the constructed area (Fig. 8-left graph-) also Málaga stands out widely (748 ha), almost with the same area as the rest of the other 3 provinces as a whole, followed by Cádiz and Almería with values close to 300 hectares and finally Granada with 229 hectares.

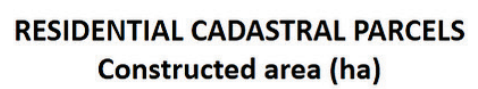

Constructed area (ha)

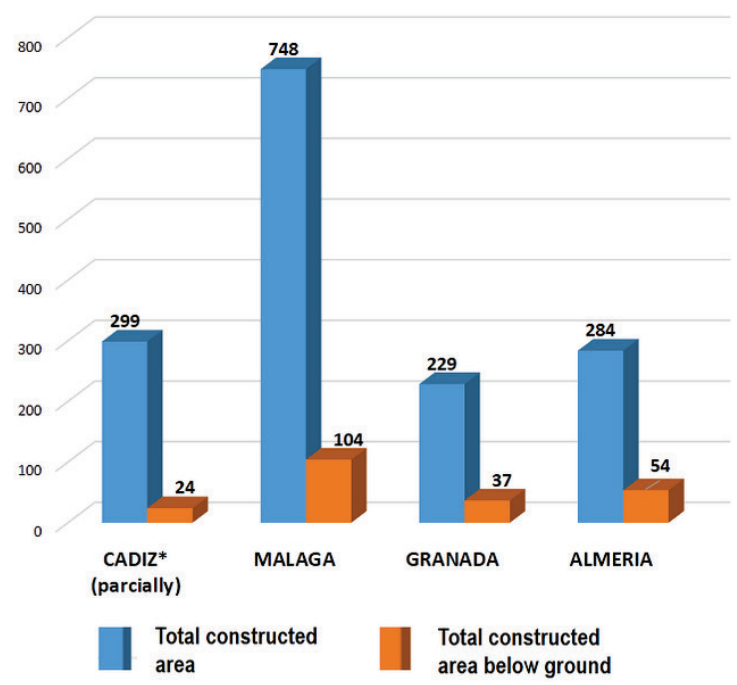

No RESIDENTIAL REAL ESTATE UNITS (Inmuebles)

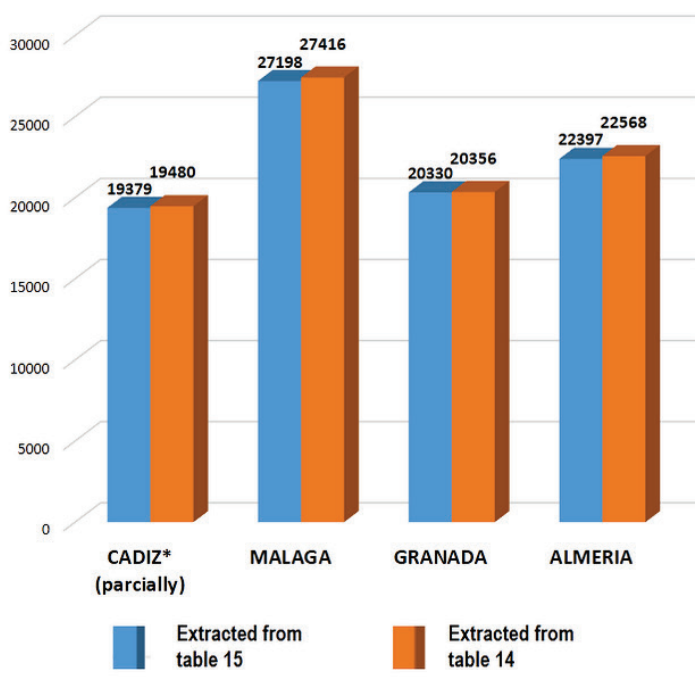

Figure 8. Constructed area in residential parcels (left graph) and number of residential real estate unitsinmuebles-as extracted from table 15 or extracted from table 14 (right graph), exposed to Jevrejeva scenario.

As stated in the methodology, the number of residential properties (residential real estate units) is the indicator selected to assess the physical vulnerability of the residential areas, in the absence of an economic estimate (not accessible to the general public in CAT format from the National Cadastre). 
Two variables were used to calculate the number of residential real estate units, one derived from table 15 (main use) and the other calculated from table 14 (constructions) with which were identified the real estate units where, at least, one "construction" had as its "destination" the residential use. As can be seen in Figure 8 (right graph), they present similar values, although the second variable (extracted from table 14) allows to identify a greater number of real estate units -inmuebles- for residential use. Therefore, this variable (number of real estate units where at least 1 construction has the residential use as destination) has been used, as an indicator, to calculate the physical vulnerability of the residential parcels. Figure 8 (right graph) clearly shows how Málaga is the province with the highest figures, followed by Almería and finally Cádiz and Granada with similar values. Finally, (see Table 4) in relation to the average probability of inundation of the residential cadastral parcels exposed to this scenario, the parcels of the province of Granada stand out widely with average values of $48 \%$, followed by those located in the provinces of Cádiz (17\%), Almeria (16\%) and, finally, Málaga with the lowest average probability values $(8.5 \%)$.

\subsection{Risk assessment for residential cadastral parcels}

Calculated the inundation hazards, exposure and physical vulnerability assessment of the residential cadastral parcels of the study area from a potential rise in mean sea level according to the models/scenarios chosen in this work, the calculation of risk (risk assessment) in each one (Table 6) has been done by multiplying all these variables that had been incorporated into the attribute table of the shape parcels. As for the previous results, the Jevrejeva model/scenario was chosen for cartography purposes since, by affecting a larger number of parcels, the cartographic representations are more understandable.

Table 6. Main figures derived exclusively from cadastral parcels exposed to Jevrejeva containing some real estate or construction units of residential use for the 4 scenarios selected.

\begin{tabular}{|l|r|r|r|r|r|r|r|r|}
\hline $\begin{array}{l}\text { Climatic } \\
\text { Scenarios }\end{array}$ & $\begin{array}{r}\mathrm{N}^{\mathrm{o}} \\
\text { cadastral } \\
\text { parcels }\end{array}$ & $\begin{array}{r}\text { Area of } \\
\text { exposed } \\
\text { parcels }\left(\mathrm{m}^{2}\right)\end{array}$ & $\begin{array}{r}\text { Total } \\
\text { constructed } \\
\text { area }\left(\mathrm{m}^{2}\right)\end{array}$ & $\begin{array}{r}\text { Total } \\
\text { constructed } \\
\text { area below } \\
\text { ground }\left(\mathrm{m}^{2}\right)\end{array}$ & $\begin{array}{r}\mathrm{N}^{\circ} \text { of real } \\
\text { estate units } \\
\left.*^{*}\right)\end{array}$ & $\begin{array}{r}\mathrm{N}^{\circ} \text { of real } \\
\text { estate units } \\
(* *)\end{array}$ & $\begin{array}{r}\text { Average } \\
\text { probability }\end{array}$ & $\begin{array}{r}\text { Average risk } \\
\text { value } \\
\text { (dimensionless } \\
\text { indicator) }\end{array}$ \\
\hline JEVJEREVA & 13,656 & $29,638,548$ & $15,592,890$ & $2,186,153$ & 89,304 & 89,820 & 22.36 & 1.43 \\
\hline RCP85 & 9,020 & $25,797,738$ & $11,741,096$ & $1,756,071$ & 61,163 & 61,289 & 14.72 & 0.86 \\
\hline RCP45 & 4,778 & $23,253,016$ & $8,916,188$ & $1,389,625$ & 40,245 & 40,419 & 19.03 & 1.18 \\
\hline RCP26 & 3,767 & $22,483,409$ & $8,089,685$ & $1,264,487$ & 35,007 & 35,144 & 21.45 & \\
\hline
\end{tabular}

* "inmuebles" with main use residential -table 15-

**at least one construction unit -table 14- with residential use

The values of the final calculation of inundation residential parcels under risk, in the absence of an economic valuation for residential real estate units, are expressed as a dimensionless indicator that has been classified with percentiles to collect a similar number of parcels in each class. This approach facilitates mapping and interpretation of results and is well suited for dimensionless indicators of this type.

Figure 9 shows -top map-, at municipalities level, the average municipality values of probability hazard and physical vulnerability of the residential cadastral parcels aggregated at each municipal level. The highest inundation probability values from the Jevrejeva model/scenario are located in most of the coastal municipalities of the province of Granada, in the eastern and western extremes of the province of Almeria, in the municipality of Fuengirola in Malaga and in those located north of the Gibraltar Rock in Cadiz. Finally, Figure 9 -bottom map- shows the comprehensive risk assessment with the dimensionless indicator calculated as the product of the previous variables, also as an average value at each municipality. 
A synthetic view of the coastal sectors with the greatest final inundation risk from potential mean sea level rise in the Jevrejeva model/scenario, at parcels scale, is shown in Figure 10. In this Figure $25 \%$ of all residential parcels were selected, once ordered according to the value of the dimensionless indicator of inundation risk - the highest fourth quartile -, and 5 percentiles were established for mapping them as proportional points. The highest "hot spots" shown by this figure are associated with residential constructed areas which occupied the coastal front of deltas/mouth of rivers (rivers as Almanzora and Adra in Almería, Guadalfeo and Verde in Granada, Vélez and Guadalhorce in Málaga and Guadiaro in Cádiz), as well as with the constructed areas on former sedimentary low lying coastal spits and beachbarrier systems (El Ejido-Almería) or with the sedimentary tombolo of Gibraltar that connects the rocky headland to the mainland in Cadiz. Especial areas also exposed to high risk are those associated with marinas and sportive ports (Benalmádena in Málaga or Sotogrande in Cádiz).

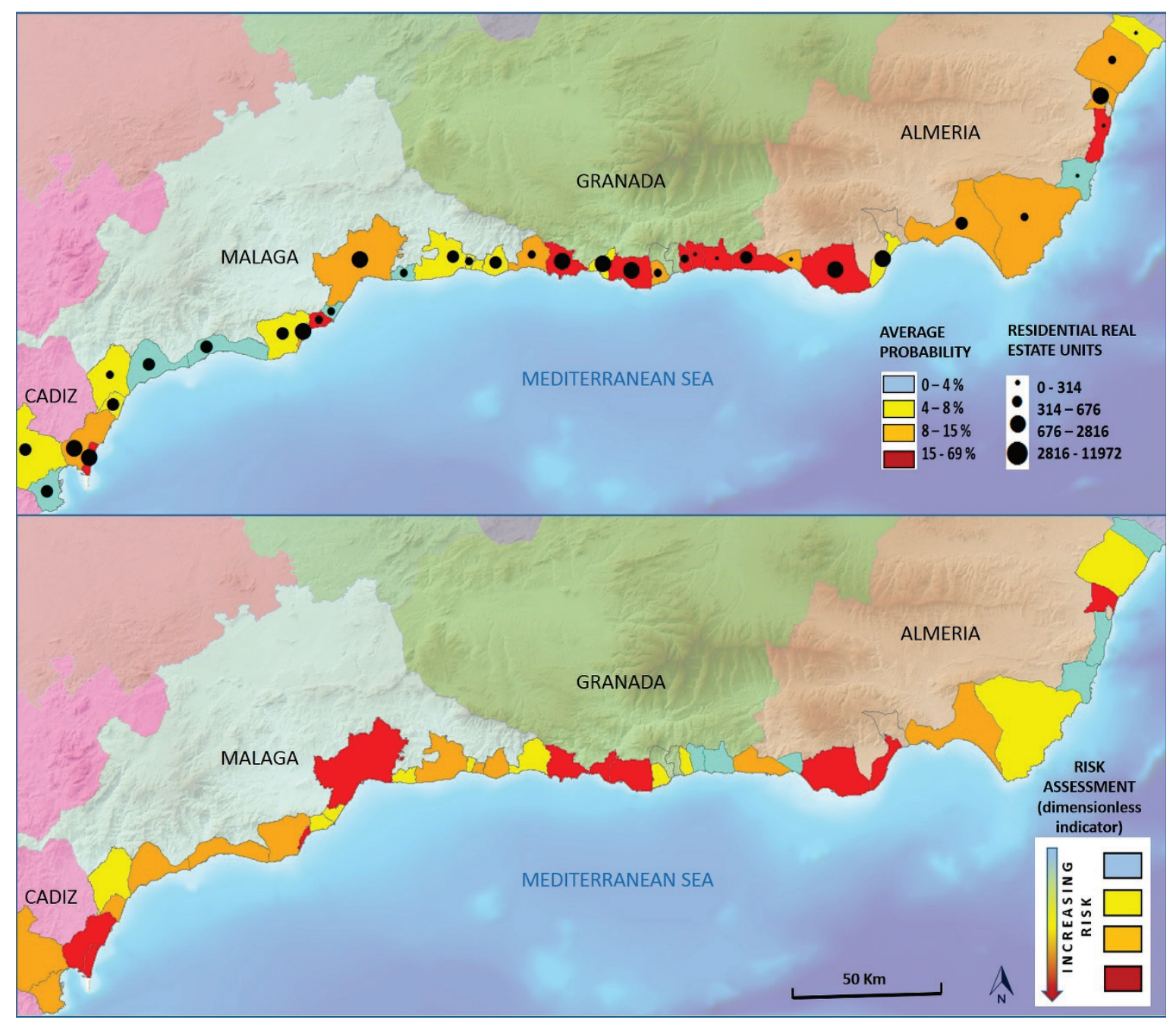

Figure 9. Average municipalities values of probability inundation hazard and residential physical vulnerability -top map - and the average municipalities values of the inundation risk dimensionless indicator -bottom map-of the residential cadastral parcels exposed to Jevrejeva model/scenario 


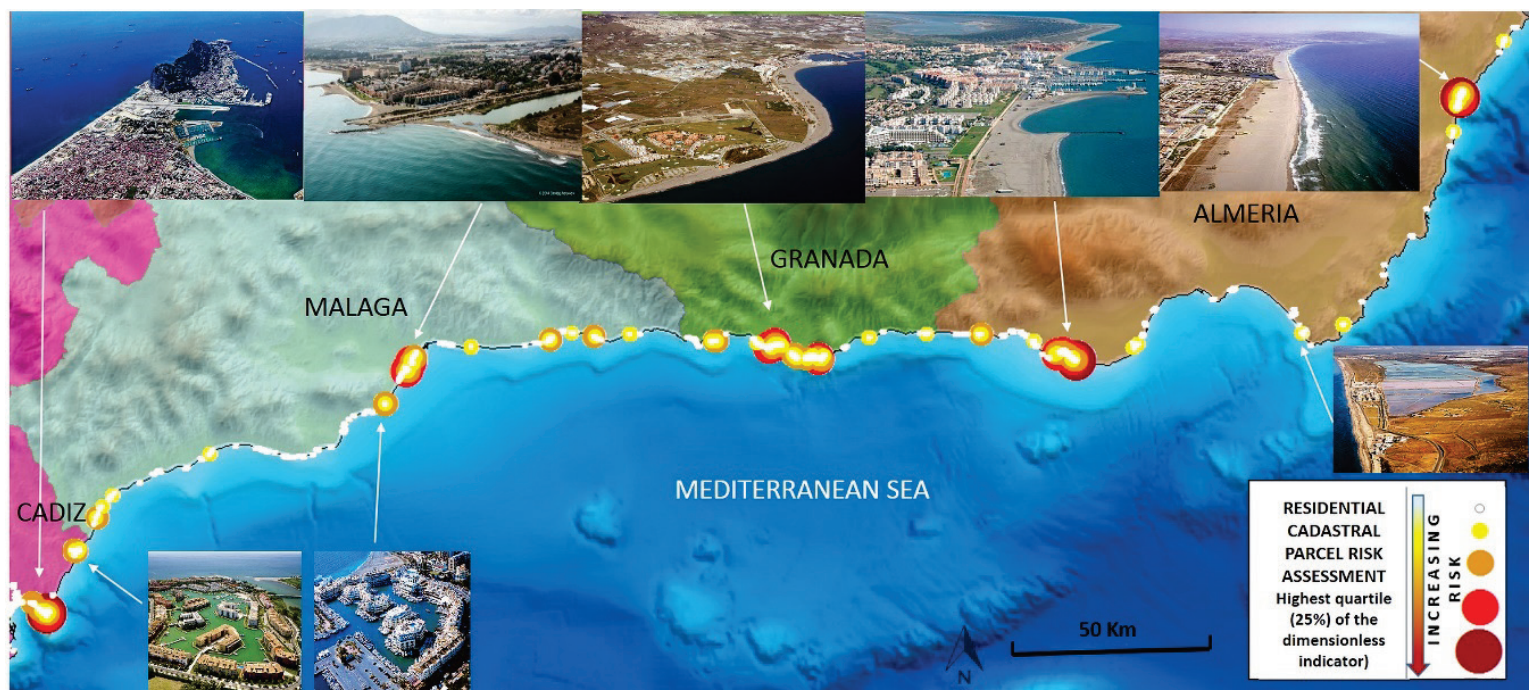

Figure 10. Synthetic map of the residential parcels (mapped as proportional points) with the highest inundation risk values (25\% -highest quartile-) from potential mean sea level rise in the Jevrejeva model/scenario.

\section{Discussion and conclusions}

The proposed methodology for the assessment of hazard, exposure and vulnerability of sea level inundation risks is considered adequate given the objectives set out in this work. In fact, it coincides with the methodology suggested by many international (UNISDR, 2004; IPCC, 2014; Wright, 2015; World Bank, 2016) and national (Kersting, 2016) organizations.

This work confirms that the proposed method of hazard mapping allows a risk analysis of high spatial detail, being mainly dependent on the quality of the input data. It is evident that the input data used can be improved by means of the vertical accuracy and spatial resolution of the DTM $(5 \mathrm{~m})$. However, one of the strengths of the proposed method is that allows working with any type of spatial resolution. In fact, the use of DTM based on LIDAR technology with a better spatial resolution would allow risk analysis at building level, even more precise than the one developed here. This phenomenon has been demonstrated in different studies (Fraile-Jurado and Ojeda-Zújar, 2013) in which it was highlighted the high sensitivity of bathtub models to the presence of vertical obstacles in DTM with medium spatial resolution $(>5 \mathrm{~m})$.

In relation to the methodology and results obtained for the physical vulnerability of residential parcels, the methodological proposal to extract residential real estate units (inmuebles) from the National Cadastre (CAT format) represents a great advance. Results have shown that using "constructions units" with residential "destination" is more efficient than the variables frequently used ("main use" of real estate units) and has allowed to identify a greater number of real estate units for residential use. On the other hand, the use of the National Cadastre, at the highest spatial level that allows mapping the assessment results (parcels), represents another major advance over other studies where the reference spatial units for vulnerability assessment are usually administrative areas, basically municipalities. The use of municipalities is in clear imbalance with the level of detail with which the hazards and exposure assessments are currently carried out due to the current availability of high precision DTM (Lidar). The recent dissemination of cadastral data with the new "atom format" (Inspire) seems promising, especially since it especially now integrates the variable number of residential real estate units (dwelling) to smaller spatial units as "building". This therefore should be further investigated.

Further, modeling and structuring of the original flat text format of National Cadastre (CAT format) in an open source spatial database management system (PostgreSQL/PostGis) has additional advantages. For instance, the guarantee of periodic updating of national cadastre and the use of SQL 
statements for the extraction of the needed variables, will allow future updates automatically and the reuse of the proposed methodology by other scientists or managers in others coastal areas.

For vulnerability and risk assessment, the economic values of the residential real estate are also critical and this, in the absence of their current availability, has been the reason for the dimensionless indicator used in this article. In this regard, recent research by Fraile et al., 2017, applied this method to a small area using a Lidar-based DTM with better planimetric and vertical accuracy and integrating the economic value of buildings. Finally, in relation to the dissemination and access to data and results in projects with this level of spatial detail, especially when new and more detailed data are incorporated (Lidar-data for the hazard exposure or building in atom format for physical vulnerability), the methodological proposal of using an application web (geoviewer) also represents a great advance and, in fact, this type of web tools are becoming irreplaceable for the work of dissemination and management in sea level risk assessment (for instance the works from https://c3e-ar4.ihcantabria.com/ or https://coast.noaa.gov/slr/\#/layer/slr).

\section{Acknowledgements}

This research was supported by the projects entitled "Mapping and Web Dissemination of residential areas and biodiversity for vulnerability and risk assessment of potential sea level rise along the Andalusia coast" (Project RNM-6207) and "e-infrastructure for spatial integration of anthropic variables for sea level rise risks assessment and web tools for coastal management in Andalusia" (P18FR-2574), both financed by the Regional Ministry of Economy, Innovation and Science (Junta de Andalucía). National project (PID2019-106834RB-I00). Ministry of Science and Innovation.

\section{References}

Álvarez-Francoso, J.I., Ojeda-Zújar, J., Díaz-Cuevas, P., Guisado-Pintado, E., Camarillo-Naranjo, J.M., PrietoCampos, A., Fraile-Jurado, P. 2020. A Specialized Geoviewer and Dashboard for Beach Erosion Rates Visualization and Exploration. Journal of Coastal Research 95 (sp1), 1006-1010. https://doi.org/10.2112/SI95-196.1

Church, J.A., Clark, P.U., Cazenave A., Gregory, J.M., Jevrejeva, S., Levermann, A., Merrifield, A.M., Milne, G.H., Nerem, R.S., Num, P.D., Payne, A.J., Pfeffer, W.T., Stammenr, D., Unnikrishnam, A.S. 2013. Sealevel rise by 2100. Science 342 (6165), 1445-1445

Fraile-Jurado, P., Ojeda Zújar, J. 2012. Evaluación de la peligrosidad asociada al aumento de la superficie inundable por la subida del nivel medio del mar en la costa entre Cádiz y Tarifa. Geofocus. Revista Internacional de Ciencia y Tecnología de la Información Geográfica 12, 329-348.

Fraile-Jurado, P., Ojeda-Zújar, J. 2013. The importance of the vertical accuracy of digital elevation models in gauging inundation by sea level rise along the Valdelagrana beach and marshes (Bay of Cádiz, SW Spain). Geo-Marine Letters 33 (2-3), 225-230. https://doi.org/10.1007/s00367-012-0317-8

Fraile-Jurado, P., Fernández Díaz, M. 2016. Escenarios de subida del nivel medio del mar en los mareógrafos de las costas peninsulares de España en el año 2100. Estudios Geográficos 280, 57-79

Fraile-Jurado, P., Sánchez-Carnero, N., Ojeda Zújar, J. 2014. Sensibilidad del cálculo de los niveles medios del mar al método y período de las series temporales de los mareógrafos en los procesos de inundación: Valdelagrana (Cádiz). Boletín de la Asociación de Geógrafos Españoles 65, 59-70.

Fraile-Jurado, P., Álvarez-Francoso, J.I., Guisado-Pintado, E., Sánchez-Carnero, N., Ojeda-Zújar, J., Leatherman, S.P. 2017. Mapping inundation probability due to increasing sea level rise along El Puerto de Santa María (SW Spain). Natural Hazards 87 (2), 581-598. https://www.doi.org/10.1007/s11069-017-2782-X

Fraile-Jurado, P., Iglesias-Campos, A. Simón-Colina, A., Hodgson, N. 2019. Methods for assessing current and future coastal vulnerability to sea level rise. A review for a case-study in Europe. European Journal of Geography 10 (3), 97-119. 
Ojeda-Zújar et al.

Gardner, A.S., Moholdt, G., Cogley, J.G., Wouters, B., Arendt, A.A., Wahr, J., Berthier, E., Hock, R., Pfeffer, W.T., Kaser, G., Ligtenberg, S.R.M., Bolch, T., Sharp, M.J., Hagen, J.O., van den Broeke, M.R., Paul, F. 2013. A reconciled estimate of glacier contributions to sea level rise: 2003 to 2009. Science 340 (6134), 852-857. https://www.doi.org/10.1126/science.1234532

Gesch, D.B. 2018. Best practices for elevation-based assessments of sea-level rise and coastal flooding exposure. Frontiers in Earth Science 6, 230. https://doi.org/10.3389/feart.2018.00230

Gregory, J. 2013. Projections of sea level rise. In: IPCC (Intergovernmental panel on Climate change), Eds. Climate Change 2013: The Physical Science Basis. Cambridge University Press, Cambridge, United Kingdom and New York, NY, USA.

Instituto Geográfico Nacional. 2013. Modelo Digital de Elevaciones. 5 metros. Available at http://centrodedescargas.cnig.es/CentroDescargas (last access: 12/06/2020)

IPCC. 2013. Working Group I Contribution to the IPCC Fifth Assessment Report: Climate Change 2013: The Physical Science Basis, Summary for Policymakers. IPCC, UN.

IPCC. 2014. AR5 Climate Change 2014: Impacts, Adaptation, and Vulnerability. Available at https://www.ipcc.ch/report/ar5/wg2/ (last access: 17/06/2020).

IPCC. 2019: Summary for Policymakers. In: H. O. Pörtner, D. C. Roberts, V. Masson-Delmotte, P. Zhai, M. Tignor, E. Poloczanska, K. Mintenbeck, M. Nicolai, A. Okem, J. Petzold, B. Rama, N. Weyer (Eds.). IPCC Special Report on the Ocean and Cryosphere in a Changing Climate, Geneva, Switzerland.

Jevrejeva, S., Moore, J.C., Grinsted, A. 2012. Sea level projections to AD2500 with a new generation of climate change scenarios. Global and Planetary Change 80, 14-20. https://doi.org/10.1016/j.gloplacha.2011.09.006

Johansson, M.M., Pellikka, H., Kahma, K.K., Ruosteenoja, K. 2014. Global sea level rise scenarios adapted to the Finnish coast. Journal of Marine Systems 129, 35-46. https://doi.org/10.1016/j.jmarsys.2012.08.007

Jongman, B., Koks, E.E., Husby, T.G., Ward, P.J. 2014. Financing increasing flood risk: evidence from millions of buildings. Natural Hazards and Earth System Sciences Discussions 2(1), 137-165. https://doi.org/10.5194/nhessd-2-137-2014

Junta de Andalucía. 2016. Plan estratégico de marketing turístico Horizonte 2020. Available at https://www.turismoandaluz.com/pemth2020/data/capitulo3.html (last access: 21/11/2020).

Kersting, D. 2016. Cambio climático en el medio marino español: impactos, vulnerabilidad y adaptación. Ministerio de Agricultura, Alimentación y Medio Ambiente, Centro de Publicaciones.

Kopp, R.E., Hay, C.C., Little, C.M., Mitrovica, J.X. 2015. Geographic variability of sea-level change. Current Climate Change Reports 1(3), 192-204. https://doi.org/10.1007/s40641-015-0015-5

Manno, G., Anfuso, G., Messina, E., Williams, A.T., Suffo, M., Liguori, V. 2016. Decadal evolution of coastline armouring along the Mediterranean Andalusia littoral (South of Spain). Ocean Coastal Management 124, 84-99. https://doi.org/10.1016/j.ocecoaman.2016.02.007

Meyssignac, B., Cazenave, A. 2012. Sea level: a review of present-day and recent-past changes and variability. Journal of Geodynamics 58, 96-109. https://doi.org/10.1016/j.jog.2012.03.005

Nicholls, R.J., Cazenave, A. 2010. Sea-level rise and its impact on coastal zones. Science 328 (5985), 1517-1520. https://doi.org/10.1126/science.1185782

Ojeda, J., Álvarez, J.I., Martín, D., Fraile, P. 2009. El uso de las TIG para el cálculo del indice de vulnerabilidad costera (CVI) ante una potencial subida del nivel del mar en la costa andaluza (España). GeoFocus. Revista Internacional de Ciencia y Tecnología de la Información Geográfica 9, 83-100.

Pérez-Morales, A., Gil-Guirado, S., Olcina, J. 2016. La información catastral como herramienta para el análisis de la exposición al peligro de inundaciones en el litoral mediterráneo español. Eure 42 (127), 231-256.

Pfeffer, W.T., Harper, J.T., O'Neel, S. 2008. Kinematic constraints on glacier contributions to 21st-century sealevel rise. Science 321 (5894), 1340-1343. https://doi.org/10.1126/science.1159099 
Piña-Monarrez, M. R. 2015. Desarrollo de la Función Densidad de Probabilidad (pdf) de la Distribución Normal y su Aplicación. Cultura Científica y Tecnológica 45.

Purvis, M.J., Bates, P.D., Hayes, C.M. 2008. A probabilistic methodology to estimate future coastal flood risk due to sea level rise. Coastal Engineering 55(12), 1062-1073. https://doi.org/10.1016/j.coastaleng.2008.04.008

Rahmstorf, S. 2007. A semi-empirical approach to projecting future sea-level rise. Science 315 (5810), 368-370. https://doi.org/10.1126/science. 1135456

Rahmstorf, S. 2010. A new view on sea level rise. Nature Climate Change 1(1004), 44-45. https://doi.org/10.1038/climate.2010.29

Rignot, E., Velicogna, I., van den Broeke, M.R., Monaghan, A., Lenaerts, J.T. 2011. Acceleration of the contribution of the Greenland and Antarctic ice sheets to sea level rise. Geophysical Research Letters 38 (5). https://doi.org/10.1029/2011GL046583

Sayol, J.M., Marcos, M. 2018. Assessing flood risk under sea level rise and extreme sea levels scenarios. Application to the Ebro Delta (Spain). Journal of Geophysical Research: Oceans 123, 794-811. https://doi.org/10.1002/2017JC013355

Shepherd, A., Wingham, D. 2007. Recent sea-level contributions of the Antarctic and Greenland ice sheets. Science 315 (5818), 1529-1532. https://doi.org/10.1126/science.113677

Smith, B., Wandel, J. 2006. Adaptation, adaptive capacity and vulnerability. Global Environmental Change 16 (3), 282-292. https://doi.org/10.1016/j.gloenvcha.2006.03.008

Tascón-González, L., Ferrer-Julià, M., Ruiz, M., García-Meléndez, E. 2020. Social Vulnerability Assessment for Flood Risk Analysis. Water 12 (2), 558. https://doi.org/10.3390/w12020558

Titus, J.G., Narayanan, V.K. 1995. The probability of sea level rise. US Environmental Protection Agency, Office of Policy, Planning, and Evaluation, Climate Change Division, 185 pp.

United Nations Office for Disaster Risk Reduction (UNISDR) 2004. Living with risk: a global review of disaster reduction initiatives, $429 \mathrm{p}$.

Williams, S.J. 2013. Sea-level rise implications for coastal regions. Journal of Coastal Research 63, $184-196$. https://doi.org/10.2112/SI63-015.1

World Bank. 2016. Methods in Flood Hazard and Risk Assessment. Techniques notes. Available at https://openknowledge.worldbank.org/handle/10986/22982 (last access: 17/06/2020).

Wright, D. B. 2015. Methods in Flood Hazard and Risk Assessment. World Bank, 19 p.

Zazo Cardeña, C., Goy Goy, J.L., Hillaire-Marcel, C., González Delgado, J.Á., Soler Javaloyes, V., Ghaleb, B., Dabrio, C.J. 2003. Registro de los cambios del nivel del mar durante el cuaternario en las Islas Canarias occidentales (Tenerife y La Palma). Estudios Geológicos 59 (1-4), 133-144.

Zhang, K., Dittmar, J., Ross, M., Bergh, C. 2011. Assessment of sea level rise impacts on human population and real property in the Florida Keys. Climatic Change 107(1-2), 129-146. https://doi.org/10.1007/s10584011-0080-2 